\title{
PROVISION OF MICRO CREDIT AT BANK MANDIRI BOGOR WITH THE FUZZY TSUKAMOTO METHOD
}

\author{
Susliansyah'; Nisan²; Heny Sumarno ${ }^{3}$; Hendro Priyono4; ${ }^{\text {; }}$ Linda Maulida5 \\ Information System \\ Universitas Bina Sarana Informatika, \\ www.bsi.ac.id \\ susliansyah.slx@bsi.ac.id ${ }^{1}$, heny_nyno@yahoo.com ${ }^{3}$, \\ hendrop250@gmail.com ${ }^{4}$, linda.lma@bsi.ac.id ${ }^{5}$ \\ Information System \\ Sekolah Tinggi Manajemen Informatika dan Komputer Nusa Mandiri \\ www.nusamandiri.ac.id \\ asyifathir8@gmail.com²
}

\begin{abstract}
It is an advantage for the bank, in this case, the Bank Mandiri Dramaga1 Bogor Unit, because of the increasing credit activity in banks, it is necessary to have an assessment in credit as consideration for prospective customers before the bank decides to accept or reject a prospective customer request. So it is necessary to develop a method that can assist and facilitate the bank in making decisions quickly and accurately. The basis for decision making is based on the criteria for determining who is eligible or not to receive a loan. To assist in determining whether someone is eligible or not to receive a loan, a decision support system is needed using fuzzy logic and applying the Tsukamoto method. The Lending Decision Support System was created to assist and facilitate the bank in making decisions to provide alternatives if a prospective customer applies for credit is accepted or not.
\end{abstract}

Keywords: Lending of Credit; Micro Credit; Fuzzy Tsukamoto

Abstrak- Merupakan suatu keuntungan bagi pihak bank dalam hal ini Bank Mandiri Unit Dramaga1 Bogor, karena semakin meningkatnya kegiatan perkreditan pada perbankan, maka perlu adanya penilaian dalam perkreditan sebagai bahan pertimbangan bagi calon nasabah sebelum pihak bank memberi keputusan menerima atau menolak permintaan calon nasabah. Maka diperlukan untuk membangun suatu metode yang dapat membantu dan mempermudah pihak bank dalam memberikan keputusan secara cepat dan tepat. Dasar dalam pengambilan keputusan berpedoman pada kriteriakriteria untuk menentukan siapa yang layak dan tidaknya untuk menerima pinjaman, untuk membantu dalam menetapkan seseorang layak atau tidaknya menerima pinjaman dibutuhkan sebuah sistem pendukung keputusan dengan menggunakan logika fuzzy dan menerapkan metode tsukamoto. Sistem Pendukung Keputusan Pemberian Kredit dibuat untuk membantu dan mempermudah pihak bank dalam mengambil keputusan untuk memberikan alternatif-alternatif dalam hal diterima atau tidaknya pengajuan kredit calon nasabah.

Kata Kunci: Pemberian Kredit; Kredit Mikro; Fuzzy Tsukamoto

\section{INTRODUCTION}

PT. Bank Mandiri Dramaga1 Bogor Unit is currently providing loans to borrowers (Lailiyah, 2014) must fill out a Credit Application Form, an initial selection process to check the suitability of data from prospective customers. Which includes personal data, business feasibility, income data, and loan data, most recently collateral data.

Then an examination is carried out both from BI Checking and a visit to the customer's business location, after credit analysis and the ability to pay from the customer are carried out, then the analyst team and Bank leadership can determine whether or not the customer is eligible for a loan (Tanjung, Mesran, Tampubolon, Suginam, \& Sianturi, 2018), (Frieyadie \& Setiyawan, 2020).

However, the credit distribution system causes the assessment of credit disbursement to be subjective, long, and inaccurate in determining customers (Bayyinah \& Usino, 2019). Credit is the main business in the banking world, where the average amount of assets owned by banks in developed and developing countries are bound in the form of credit (Pato, 2013). The process of providing credit requires good consideration and analysis from bank leaders, due to the high number of non-performing loans (Sari \& Sindunata, 2014). 
To avoid possible losses (Herlina, 2018) that will be suffered by the bank due to customers who do not fulfill their obligations according to the agreement. Many factors must be considered when making decisions (Yasdomi, 2015) in the implementation of credit extension (Salim, 2015), which are strongly influenced by the provisions and policies of the Bank leadership.
The purpose of this research is to determine the requirements and process of providing microcredit and to assist the bank in determining the feasibility of a prospective debtor to be given credit quickly and effectively.

The research journals that are similar to this research are as follows:

Table 3. Literature Research

\begin{tabular}{llll}
\hline Author & Problems & Method & Result \\
\hline Eliska & So far, PT. Interface Mitra Mandiri still uses & FIS & The system built can help \\
Sulistiani dan & subjective assessment, which is to determine the & Tsukamoto & companies manage the \\
Shandi Noris & feasibility of granting credit, namely by using survey & method & credit application data \\
& $\begin{array}{l}\text { personnel who are considered to be more familiar } \\
\text { storage system to be better }\end{array}$ & & than before.
\end{tabular}

Noris, 2016) condition of prospective debtors, from following up prospective debtors, surveying the residence, environment and workplaces/business, and likewise the collection of required data from prospective debtors is carried out by surveyors. In making decisions that are feasible or not feasible, it is carried out based on instructions from the surveyor to the analyst team so that credit analysis by the surveyors and decision making by the local analyst team is less accurate.

\begin{tabular}{ll}
\hline Nur Sakinah & So far, the BPR often finds mistakes in providing \\
Tanjung, & credit to customers. As it is often found that \\
Mesran, & customers who do not deserve to be given credit \\
Kennedi & receive credit because of the system of knowing \\
Tampubolon, & insiders and the system of knowing relatives or \\
Suginam, & close people which makes bank employees negligent \\
Maringan & in their duties to select prospective customers based \\
Sianturi & on predetermined criteria, which results in \\
& problems when credit payments.
\end{tabular}

$\begin{array}{ll}\text { Tsukamoto } & \text { Assist and facilitate the } \\ \text { method } & \text { bank as the decision-maker } \\ & \text { to provide alternatives if } \\ & \text { credit applicants are } \\ & \text { accepted or not. }\end{array}$

(Tanjung et al., 2018)

$\begin{array}{ll}\begin{array}{l}\text { Sri Kurniasih } \\ \text { dan Lovita Sari }\end{array} & \begin{array}{l}\text { Koperasi Kemuning Persada (KKP) is a company } \\ \text { engaged in the provision of credit services, where } \\ \text { the main task of the KKP is to consider the size of the } \\ \text { loan that will be given to prospective customers. }\end{array} \\ \begin{array}{l}\text { (Kurniasih \& } \\ \text { Ginting, 2020) }\end{array} & \begin{array}{l}\text { Often there are errors in providing loans to } \\ \text { prospective customers because the assessments } \\ \text { used as parameters are not objective, especially in } \\ \text { determining the value of the size of the credit loan } \\ \text { proposed, this has resulted in several problems in } \\ \text { terms of decisions that must be taken by the head of } \\ \text { the related branch. }\end{array}\end{array}$

Fuzzy

Tsukamoto

Method
1. Can make it easier for branch heads in making decisions on credit extension and eligibility to customers.

2. Helping fast decisions and the accuracy of customer data that is always available in determining eligibility criteria for credit applications, this information can be seen in the report

\begin{tabular}{|c|c|c|c|}
\hline $\begin{array}{l}\text { Tri Murti, } \\
\text { Leon Andretti } \\
\text { Abdillah, } \\
\text { Muhammad } \\
\text { Sobri } \\
\text { (Murti, } \\
\text { Abdillah, \& } \\
\text { Sobri, 2015) }\end{array}$ & $\begin{array}{l}\text { PT Triprima Finance is a company engaged in } \\
\text { lending services with collateral in the form of a } \\
\text { motorized vehicle owner's book or a car (BPKB). To } \\
\text { provide good service to customers, PT Triprima } \\
\text { Finance must consider loans from its customers } \\
\text { with the approval of the head manager. Such } \\
\text { approval can take a long time as it has to go through } \\
\text { many stages of reporting procedures. So far, } \\
\text { decision-making activities at PT. Triprima Finance } \\
\text { has been carried out by manual analysis by }\end{array}$ & $\begin{array}{l}\text { Fuzzy } \\
\text { Tsukamoto } \\
\text { method }\end{array}$ & $\begin{array}{l}\text { 1. Make it easier for } \\
\text { management to } \\
\text { determine loan eligibility } \\
\text { to make it faster and } \\
\text { more accurate. } \\
\text { 2. This system also makes it } \\
\text { easy to provide reports to } \\
\text { the Kaposko and branch } \\
\text { managers and makes it } \\
\text { easier for surveyors to }\end{array}$ \\
\hline
\end{tabular}




\begin{tabular}{|c|c|c|c|}
\hline Author & Problems & Method & Result \\
\hline & considering customer data. & & $\begin{array}{l}\text { provide reports on } \\
\text { survey results. } \\
\text { 3. This system will generate } \\
\text { values and decisions to } \\
\text { determine the feasibility } \\
\text { of a loan. Based on the } \\
\text { highest total value of the } \\
\text { loan application. }\end{array}$ \\
\hline $\begin{array}{l}\text { Wilis } \\
\text { Kaswidjanti, } \\
\text { Agus Sasmito } \\
\text { Aribowo, } \\
\text { Cahyo Budi } \\
\text { Wicaksono } \\
\text { (Kaswidjanti, } \\
\text { Ariwibowo, \& }\end{array}$ & $\begin{array}{l}\text { At this time the need for housing has increased } \\
\text { rapidly so that homeownership credit (KPR) has } \\
\text { developed, this can be seen from the number of } \\
\text { banks in Indonesia that offer KPR with various } \\
\text { offers with different terms and conditions. The } \\
\text { development of increasingly complex mortgages } \\
\text { requires a computerized system to help prospective } \\
\text { borrowers know the feasibility of taking a KPR. }\end{array}$ & $\begin{array}{l}\text { fuzzy } \\
\text { inference } \\
\text { system (FIS) } \\
\text { Tsukamoto } \\
\text { method }\end{array}$ & $\begin{array}{l}\text { Make it easier for } \\
\text { prospective debtors to } \\
\text { apply for KPR, assist } \\
\text { prospective borrowers to } \\
\text { manage finances before } \\
\text { applying for KPR, and assist } \\
\text { banks/housing developers } \\
\text { in marketing. }\end{array}$ \\
\hline
\end{tabular}

2014)

Source: (Susliansyah et al., 2020)

\section{MATERIALS AND METHODS}

\section{A. Fuzzy Tsukamoto}

Extensions of monotone reasoning. In Tsukamoto's method, each consequent in the IFTHEN form must be represented by a fuzzy set with a monotonous membership function. As a result, the inference result of each rule is given crisp based on $\alpha$ - predicate (fire strength). The final result is obtained using weighted averages. (Sofyan, Sayuti, \& Julianda, 2018).

The completion of the method for Fuzzy Tsukamoto is as follows:

1. Fuzzyfication

Changing input systems that have explicit values into linguistic variables (fuzzification) In fuzzification, the input variable (crisp) of the fuzzy system is transferred into the fuzzy set to be used in calculations. Each variable has 3 fuzzy sets, namely: Very Good, Fairly Good, Not Good.

Assessment evaluation variables This process is used to calculate the membership value which consists of several inputs, namely the variables that affect the calculation.

2. Establishment of a fuzzy knowledge base (rules in the form of IF..THEN). In designing this rule contains rules that apply to all events (combinations). This process is used to find a fuzzy output value from the fuzzy input. The process is as follows: a fuzzy input value originating from the fuzzification process is then entered into a rule that has been created to become a fuzzy output. The following is an example of using the first rule (R1) which will be used for fuzzy calculations in the IF-THEN form.

3. Inference

Using the MIN implication to get the $\alpha$ predicate value of each rule $(\alpha 1, \alpha 2, \alpha 3, . . \alpha \mathrm{n})$.

$$
\begin{aligned}
\mathrm{z}=\sum_{0}^{1}(50-\mathrm{z}) /(50-0), 0 & \leq \mathrm{z} \leq 50 \ldots \ldots \ldots \ldots \ldots \ldots \\
\mathrm{z} & \leq 50 \\
\mathrm{z} & \leq 0 \\
\mathrm{z}=\sum_{1}^{0}(\mathrm{z}-50) /(100-50), & 50 \leq \mathrm{z} \leq 100 \ldots \\
\mathrm{z} & \leq 50
\end{aligned}
$$

Then each of these $\alpha$-predicate values is used to calculate the crisp inference output for each rule $(\mathrm{z} 1, \mathrm{z} 2, \mathrm{z} 3, \ldots . \mathrm{zn})$.

4. Defuzzification.

The input of the defuzzification process is a fuzzy set (resulting from the composition process) and the output is a value (crisp). Using the average method (Average).

$$
\mathrm{Z} *=\sum \frac{\alpha \mathrm{iz} 1}{\alpha \mathrm{i}}
$$

Defuzzification process The final output $(\mathrm{z})$ is obtained by using the weighted average (mean):

$\mathrm{z}=\frac{\alpha 1+\alpha 2 \mathrm{z} 2}{\alpha 1+\alpha 2}$

In selecting loan applications at Bank Mandiri Dramaga1 Bogor Unit, criteria and weights are needed to perform calculations so that the best alternative will be obtained. The criteria for loans 
according to (Kasmir, which have been determined as follows:

Table 1. Loan Criteria

\begin{tabular}{|c|c|}
\hline Criteria C & Explanation \\
\hline $\mathrm{C} 1$ & Character \\
\hline $\mathrm{C} 2$ & Capital \\
\hline $\mathrm{C} 3$ & Capacity \\
\hline $\mathrm{C} 4$ & Collateral \\
\hline $\mathrm{C} 5$ & Condition \\
\hline
\end{tabular}

Table 1 above is the criteria used for calculations in determining the provision of credit to prospective borrowers. From these criteria, a criterion level of importance is determined based on the weight values that have been determined into fuzzy numbers. The rating of the suitability of each alternative on each criterion is as follows:

Table 2. Loan Criteria Weights

\begin{tabular}{llc}
\hline \multicolumn{1}{c}{ Criteria C } & \multicolumn{1}{c}{ Explanation } & Weight \\
\hline C1 & Character & 20 \\
\hline C2 & Capital & 25 \\
\hline C3 & Capacity & 15 \\
\hline C4 & Collateral & 25 \\
\hline C5 & Condition & 15 \\
\hline
\end{tabular}

Source:(Kasmir, 2016)

Table 2 above is to determine a criterion importance level based on the weight value that has been determined into fuzzy numbers.

Table 3. Input Variables

\begin{tabular}{lc}
\hline \multicolumn{1}{c}{ Fuzzy numbers } & Score \\
\hline Very Good & $80-100$ \\
\hline Quite Good & $50-70$ \\
\hline Not Good & $10-40$ \\
\hline \multicolumn{2}{c}{$\begin{array}{c}\text { Source: (Susliansyah, Nisan, } \\
\text { Maulida, 2020) }\end{array}$}
\end{tabular}

Table 3 above gives the input variable values to fuzzy numbers.

Table 4. Output Variables

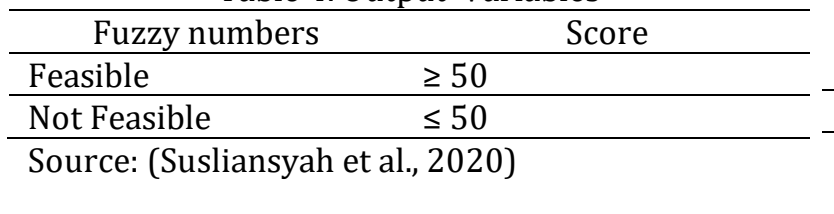

Table 4 above gives the output variable values to fuzzy numbers. Furthermore, based on the criteria of the suitability rating of each alternative on each predetermined criterion, then the translation of the weight of each criterion that has been converted into a fuzzy number.

Table 5. Character

\begin{tabular}{clc}
\hline Criteria C & Explanation & Score Crips \\
\hline \multirow{3}{*}{ Character } & Very Good & 100 \\
\cline { 2 - 3 } & Quite Good & 70 \\
\cline { 2 - 3 } & Not Good & 40
\end{tabular}

Source: (Susliansyah et al., 2020)

Table 5 describes the value of the criteria that have been converted into fuzzy numbers.

Table 6. Capital

\begin{tabular}{ccc} 
Criteria & Explanation & $\begin{array}{c}\text { Score } \\
\text { Crips }\end{array}$ \\
\hline \multirow{3}{*}{ Capital } & Very Good $(\geq 51$ juta $)$ & 100 \\
\cline { 2 - 3 } & Quite Good $(26-50$ juta $)$ & 70 \\
\cline { 2 - 3 } & Not Good $(10-25$ juta $)$ & 40 \\
\hline
\end{tabular}

Source: (Susliansyah et al., 2020)

Table 6 describes the value of the capital that has been converted into fuzzy numbers.

\begin{tabular}{ccc}
\multicolumn{3}{c}{ Tabel 7. Capacity } \\
\hline Criteria & Explanation & Score Crips \\
\hline \multirow{3}{*}{ Capacity } & Very Good & 100 \\
\cline { 2 - 3 } & Quite Good & 70 \\
\cline { 2 - 3 } & Not Good & 40
\end{tabular}

Source: (Susliansyah et al., 2020)

Table 7 describes the value of the capacity that has been converted into fuzzy numbers.

Table 8. Collateral

\begin{tabular}{ccc}
\hline Criteria & Explanation & $\begin{array}{c}\text { Score } \\
\text { Crips }\end{array}$ \\
\hline \multirow{3}{*}{ Collateral } & Very Good (SHM) & 100 \\
\cline { 2 - 3 } & Quite Good (AJB) & 70 \\
\cline { 2 - 3 } & Not Good (BPKB) & 40
\end{tabular}

Source: (Susliansyah et al., 2020)

Table 8 describes the value of the collateral that has been converted into fuzzy numbers.

Table 9. Condition

\begin{tabular}{ccc}
\hline Criteria & Explanation & Score Crips \\
\hline \multirow{3}{*}{ Condition } & Very Good & 100 \\
\cline { 2 - 3 } & Quite Good & 70 \\
\cline { 2 - 3 } & Not Good & 40 \\
\hline
\end{tabular}

Source: (Susliansyah et al., 2020) 
Table 9 describes the value of the condition that has been converted into fuzzy numbers.

\section{RESULTS AND DISCUSSION}

There are several steps to make calculations to determine a potential customer who deserves credit using the Fuzzy Tsukamoto method as follows:

The data on the alternative weight value of prospective debtors for Bank Mandiri (Persero) Tbk, Bogor Dramaga1 Unit step one (1) determine the alternative, namely A1. Here are 21 alternative data that will be sampled.

Table 10. Alternative Weight Values

\begin{tabular}{llccccc}
\hline \multirow{2}{*}{ No } & \multirow{2}{*}{ Debtor's Name } & \multicolumn{5}{c}{ Criteria } \\
\cline { 2 - 7 } & C1 & C2 & C3 & C4 & C5 \\
\hline 1 & $\begin{array}{l}\text { Julianto Firman } \\
\text { Nugraha (A1) }\end{array}$ & 90 & 70 & 80 & 70 & 65 \\
\hline 2 & Odih (A2) & 70 & 80 & 90 & 70 & 65 \\
\hline 3 & $\begin{array}{l}\text { Cucu Widiawati } \\
\text { (A3) }\end{array}$ & 65 & 75 & 80 & 90 & 70 \\
\hline 4 & Atin (A4) & 80 & 90 & 70 & 70 & 65 \\
\hline 21 & $\begin{array}{l}\text { Oka Andiliyana } \\
\text { (A21) }\end{array}$ & 90 & 65 & 65 & 70 & 70 \\
\hline
\end{tabular}

Source: (Susliansyah et al., 2020)

Table 10 above describes the value of each criterion for prospective Bank Mandiri debtors.

A. The steps for solving the fuzzy using the Tsukamoto method are as follows:

\section{Fuzzification}

Explanation of the calculation of Character membership degrees.

a. $\mu$ Not Good Condition [90]

$=\mathrm{x} \geq 40$

$=90 \geq 40$

Then $=0$

b. $\mu$ Quite Good Condition [90]

$=50 \leq \mathrm{x} \geq 100$

$=50 \leq 90 \geq 100$

Then $=(100-\mathrm{x}) /(100-50)$

$=(100-90) /(100-50)$

$=10 / 50$

$=0,2$

c. $\mu$ Very Good Condition [90]

$=60 \leq \mathrm{x} \geq 100$

$=60 \leq 90 \geq 100$

Then $=(x-60) /(100-60)$

$=(90-60) /(100-60)$

$=30 / 40$
$=0,75$

Explanation of the calculation of Capacity membership degrees.

a. $\mu$ Not Good Condition [70]

$=\mathrm{x} \geq 40$

$=70 \geq 40$

Then $=0$

b. $\mu$ Quite Good Condition [70]

$=50 \leq \mathrm{x} \geq 100$

$=50 \leq 70 \geq 100$

Then $=(100-\mathrm{x}) /(100-50)$

$=(100-70) /(100-50)$

$=30 / 50$

$=0,6$

c. $\quad \mu$ Very Good Condition [70]

$=60 \leq \mathrm{x} \geq 100$

$=60 \leq 70 \geq 100$

Then $=(\mathrm{x}-60) /(100-60)$

$=(70-60) /(100-60)$

$=10 / 40$

$=0,25$

Explanation of the calculation of Capital membership degrees.

a. $\mu$ Not Good Condition [80]

$=\mathrm{x} \geq 40$

$=80 \geq 40$

Then $=0$

b. $\quad \mu$ Quite Good Condition [80]

$=50 \leq \mathrm{x} \geq 100$

$=50 \leq 80 \geq 100$

Then $=(100-\mathrm{x}) /(100-50)$

$=(100-80) /(100-50)$

$=20 / 50$

$=0,4$

c. $\mu$ Very Good Condition [80]

$=60 \leq \mathrm{x} \geq 100$

$=60 \leq 80 \geq 100$

Then $=(\mathrm{x}-60) /(100-60)$

$=(80-60) /(100-60)$

$=20 / 40$

$=0,5$

Explanation of the calculation of Collateral membership degrees.

a. $\mu$ Not Good Condition [70]

$=\mathrm{x} \geq 40$

$=70 \geq 40$

Then $=0$

b. $\quad \mu$ Quite Good Condition [70]

$=50 \leq \mathrm{x} \geq 100$

$=50 \leq 70 \geq 100$

Then $=(100-x) /(100-50)$ 


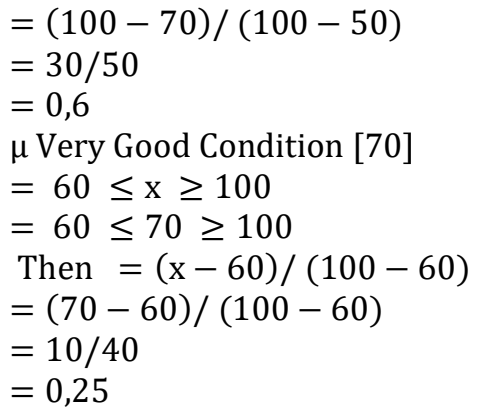

Explanation of the calculation of Condition membership degrees.

Table 11. Memberships Degrees A1

\begin{tabular}{clccccc}
\hline No & $\begin{array}{c}\text { Input } \\
\text { Variable }\end{array}$ & Criteria & Score & \multicolumn{3}{c}{$\begin{array}{c}\text { Memberships } \\
\text { Degrees }\end{array}$} \\
\cline { 4 - 7 } & & & & KB & CB & SB \\
\hline 1 & Character & SB & 90 & 0 & 0,2 & 0,75 \\
\hline 2 & Capital & CB & 70 & 0 & 0,6 & 0,25 \\
\hline 3 & Capacity & SB & 80 & 0 & 0,4 & 0,5 \\
\hline 4 & Collateral & CB & 70 & 0 & 0,6 & 0,25 \\
\hline 5 & Condition & CB & 65 & 0 & 0,25 & 0,125 \\
\hline
\end{tabular}

Source: (Susliansyah et al., 2020)

Table 11 above describes the results of calculating the degree of membership of Julianto Firman Nugraha (A1) for each criterion.

\section{Designing Rules}

Contains rules that apply to all occurrences (combinations), functions to find the output fuzzy value of fuzzy input. The process is as follows: a fuzzy input value originating from the fuzzification process is then entered into a rule that has been recorded to become a fuzzy output using the rule (R1... Rn) which will be used for fuzzy calculations in the form of IF-THEN.

\section{Inference Engine}

It is the process of processing fuzzy input into fuzzy output by following the rules that have been established in the fuzzy knowledge base. The inference engine is a MIN implication function to get the $\alpha$-predicate value of each rule. Explanation of $\alpha$-predicate and crisp ( $\mathrm{z}$ ) calculations

for R1 are as follows:

$\alpha 1=$ MIN ( $\pi$ Character VeryGood AND

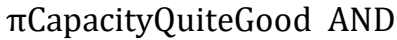

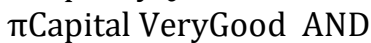

$\pi$ CollateralQuiteGood AND

$\pi$ ConditionQuiteGood)

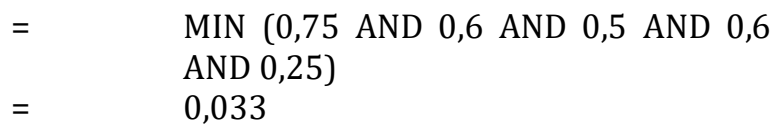

R1 which has a membership degree with a DECENT decision

$$
\begin{aligned}
& (\mathrm{z} 1-50) /(100-50)=0,033 \\
& (\mathrm{z} 1-50) \quad=0,033 * 50 \\
& \mathrm{z} 1=(0,033 * 50)+50 \\
& =1,65+50 \\
& =51,65
\end{aligned}
$$

\begin{tabular}{|c|c|c|c|c|c|c|c|c|c|}
\hline \multirow[b]{2}{*}{ Rule } & \multirow[b]{2}{*}{ IF } & \multicolumn{5}{|c|}{ Input Variable } & \multirow{2}{*}{$\begin{array}{c}\text { Output Variable } \\
\text { Evaluation } \\
\text { assessment }\end{array}$} & \multirow{2}{*}{$\begin{array}{c}\alpha- \\
\text { predicate } \\
(\mathrm{R})\end{array}$} & \multirow[b]{2}{*}{$\mathrm{Z}(\mathrm{R})$} \\
\hline & & C1 & $\mathrm{C} 2$ & C3 & $\mathrm{C} 4$ & $\mathrm{C} 5$ & & & \\
\hline \multirow[t]{2}{*}{$\mathrm{R} 1$} & IF & Very & Quite & Very & Quite & Quite & Feasible & 0,033 & 51,65 \\
\hline & & Good & Good & Good & Good & Good & & & \\
\hline \multirow[t]{2}{*}{$\mathrm{R} 2$} & IF & Quite & Very & Very & Quite & Quite & Feasible & 0,033 & 51,65 \\
\hline & & Good & Good & Good & Good & Good & & & \\
\hline \multirow[t]{2}{*}{ R3 } & IF & Quite & Very & Very & Very & Quite & Feasible & 0,003 & 50,15 \\
\hline & & Good & Good & Good & Good & Good & & & \\
\hline \multirow[t]{2}{*}{$\mathrm{R} 4$} & IF & Very & Very & Quite & Quite & Quite & Feasible & 0,033 & 51,65 \\
\hline & & Good & Good & Good & Good & Good & & & \\
\hline \multirow[t]{2}{*}{$\mathrm{R} 5$} & IF & Very & Very & Quite & Quite & Quite & Feasible & 0,028 & 51,4 \\
\hline & & Good & Good & Good & Good & Good & & & \\
\hline
\end{tabular}

Table 12. Inference Engine

Resource: (Susliansyah et al., 2020)

Table 12 above explains the results of calculations at the inference engine stage in determining whether or not a candidate is eligible for a loan.

P-ISSN: 1978-2136 | E-ISSN: 2527-676X | Provision of Micro ...

Techno Nusa Mandiri : Journal of Computing and Information Technology

As an Accredited Journal Rank 4 based on Dirjen Risbang SK No. 85/M/KPT/2020 


\section{Defuzzification}

This is done to convert the fuzzy output obtained from the inference engine into an explicit value using the appropriate membership function when fuzzification is performed. The output results are obtained from the results $(\mathrm{z})$ weighted average (Mean).

$$
\begin{aligned}
\mathrm{z} & =\frac{\alpha 1 \mathrm{z} 1+\alpha 2 \mathrm{z} 2+\alpha 3 \mathrm{z} 3+\alpha 4 \mathrm{z} 4+\alpha 5 \mathrm{z} 5}{\alpha 1+\alpha 2+\alpha 3+\alpha 4+\alpha 5} \\
& =51,5615
\end{aligned}
$$

Then the fuzzy value from the calculation of the Assessment Evaluation is 51.5615, thus the feasibility level of a prospective customer who applies for a business capital loan is $\mathbf{5 1 . 5 6 1 5 .}$

\section{CONCLUSION}

Based on the results of the research conducted, it can be concluded that the system built displays information on whether or not a prospective customer/debtor is given a business capital loan. With the fuzzy Tsukamoto method, he was able to assist Bank Mandiri Dramaga1 Bogor in providing recommendations and considerations in making credit decisions based on determined criteria. By applying the Tsukamoto fuzzy method, it can speed up the decision-making process and determine the creditworthiness of a prospective customer.

\section{REFERENCE}

Bayyinah, A., \& Usino, W. (2019). Analyzing Decision Support System for Determining Eligibility of Home Ownership Loan Using Fuzzy Mamdani Logical Method and Technology Acceptance Model in Banking. Data Science: Journal of Computing and Applied Informatics, 3(1), 58-76. https://doi.org/10.32734/jocai.v3.i1-619

Frieyadie, F., \& Setiyawan, R. (2020). IMPLEMENTATION OF THE SAW METHOD AS A DECISION SUPPORT FOR GIVING FEASIBILITY OF KUR ON BANK MANDIRI DRAMAGA BOGOR. Jurnal Pilar Nusa Mandiri, 16(1), 103-110. https://doi.org/10.33480/pilar.v16i1.1302

Herlina, N. (2018). Antisipasi Bank Untuk Menghindari Kredit Macet Yang Ditimbulkan Oleh Kerugian Debitur Akibat Pencemaran Lingkungan. Jurnal Ilmiah Galuh Justisi, 6(2), 210-226. https://doi.org/10.25157/jigj.v6i2.1715
Kasmir. (2016). DASAR-DASAR PERBANKAN. Depok.

Kaswidjanti, W., Ariwibowo, A. S., \& Wicaksono, C. B. (2014). Implementasi Fuzzy Inference System Metode Tsukamoto Pada Pengambilan Keputusan Pemberian Kredit Pemilikan Rumah. Telematika, 10(2), 137146.

https://doi.org/10.31315/telematika.v10i2.2 81

Kurniasih, S., \& Ginting, L. S. B. (2020). Sistem Pendukung Keputusan Untuk Kelayakan Pemberian Kredit Dengan Metode Fuzzy Tsukamoto (Studi Kasus Koperasi Kemuning Persada Cabang Bandung). Jurnal Nuansa Informatika, 14(1), 38-45. https://doi.org/10.25134/nuansa.v14i1.241 7

Lailiyah, A. (2014). Urgensi Analisa 5C Pada Pemberian Kredit Perbankan Untuk Meminimalisir Resiko. Yuridika, 29(2), 217232.

https://doi.org/10.20473/ydk.v29i2.368

Murti, T., Abdillah, L. A., \& Sobri, M. (2015). Sistem penunjang keputusan kelayakan pemberian pinjaman dengna metode fuzzy tsukamoto (pp. 252-256). Retrieved from http://arxiv.org/abs/1506.00091

Pato, S. (2013). ANALISIS PEMBERIAN KREDIT MIKRO PADA BANK SYARIAH MANDIRI CABANG MANADO. Jurnal EMBA, 4(4), 875885.

https://doi.org/10.1017/CB0978110741532 4.004

Salim, F. A. (2015). Analisis Penerapan Sitem Informasi Akuntansi Dalam Mendukung Pengendalian Internal Pemberian Kredit Pada Pt. Bank Bukopin Manado. Jurnal Riset Ekonomi, Manajemen, Bisnis Dan Akuntansi, 3(1), 1034-1043. https://doi.org/10.35794/emba.v3i1.7808

Sari, R. D. I., \& Sindunata, Y. (2014). PENERAPAN DATA MINING UNTUK ANALISA POLA PERILAKU NASABAH DALAM PENGKREDITAN MENGGUNAKAN METODE C.45 STUDI KASUS PADA KSU INSAN KAMIL DEMAK. Jurnal Ilmiah Teknologi Informasi Asia, 8(2), 10-16. 
Sofyan, D. K., Sayuti, M., \& Julianda. (2018). Metode Fuzzy Inference System Tsukamoto (Pertama). Yogyakarta: Teknosain.

Sulistiani, E., \& Noris, S. (2016). Penerapan fis metode tsukamoto untuk menentukan kelayakan pemberian kredit. Jurnal Informatika Universitas Pamulang, 1(1), 2227.

Susliansyah, Nisan, Sumarno, H., Priyono, H., \& Maulida, L. (2020). Pemberian Kredit Mikro Pada Bank Mandiri Bogor Dengan Metode Fuzzy Tsukamoto.

Tanjung, N. S., Mesran, Tampubolon, K., Suginam, \& Sianturi, M. (2018). Sistem Pendukung Keputusan Kelayakan Pemberian Kredit Modal Usaha Menerapkan Metode Fuzy Tsukamoto (Studi Kasus: Pt. Bpr Bina Barumun). KOMIK (Konferensi Nasional Teknologi Informasi Dan Komputer), 2(1), 376-381.

https://doi.org/10.30865/komik.v2i1.962

Yasdomi, K. (2015). Sistem Pendukung Keputusan Pemberian Kredit Modal Usaha Menggunakan Metode Weighted Product ( Studi Kasus Pada Bank Danamon Simpan Pinjam Ujung Batu ). Riau Journal of Computer Science, 1(1), 92105. 